\title{
COMPARATIVE STUDY OF EFFECTS OF MIDAZOLAM AND KETAMINE AS ORAL PREMEDICATION FOR PAEDIATRIC ANAESTHESIA
}

\author{
Shaswat Kumar Pattnaik1, Soumya Samal2, Saubhagya Kumar Jena ${ }^{3}$
}

${ }_{1}^{1}$ Associate Professor, Department of Anaesthesiology, IMS and SUM Hospital, Bhubaneswar.

${ }^{2}$ Assistant Professor, Department of Anaesthesiology, IMS and SUM Hospital, Bhubaneswar.

${ }^{3}$ Additional Professor, Department of Obstetrics and Gynaecology, AIIMS, Bhubaneswar.

ABSTRACT
BACKGROUND
The fear psychosis of surgery in children is a traumatic experience. Midazolam and ketamine are useful oral premedication to
allay anxiety.

AIM

To compare the effects of midazolam and ketamine as oral premedication in children.

\section{SETTINGS AND DESIGN}

This prospective, randomised, comparative study was conducted in a Medical College and Hospital in the Department of Anaesthesiology.

\section{MATERIAL AND METHODS}

The study subjects were 100 children posted for elective surgery under general anaesthesia. They were randomised into two groups. Group M received $0.75 \mathrm{mg} / \mathrm{kg}$ of oral midazolam and group K received $6 \mathrm{mg} / \mathrm{kg}$ of oral ketamine as premedication. Standard general anaesthesia technique was used. Level of sedation, anxiolysis, and ease of parental separation were noted.

\section{RESULTS}

Midazolam was found to have better anxiolytic action than ketamine $(\mathrm{P}<0.05)$. Onset of sedation was $16.2 \pm 3.6$ minutes with midazolam and $19.4 \pm 3.2$ minutes with ketamine $(\mathrm{P}<0.001)$. Induction score was also excellent in midazolam group $(54 \%)$ than ketamine (44\%). Side effects were also less in midazolam group.

\section{CONCLUSION}

Midazolam $(0.75 \mathrm{mg} / \mathrm{kg})$ is effective than ketamine $(6 \mathrm{mg} / \mathrm{kg})$ as oral premedicants in children because of its early onset of action, better effect on allaying anxiety during separation from parents and lesser side effects.

\section{KEYWORDS}

Anxiolysis, Children, Ketamine, Midazolam, Premedication.

HOW TO CITE THIS ARTICLE: Pattnaik SK, Samal S, Jena SK. Comparative study of effects of midazolam and ketamine as oral premedication for paediatric anaesthesia. J. Evolution Med. Dent. Sci. 2016;5(54):3611-3615, DOI: 10.14260/jemds/2016/832

\section{INTRODUCTION}

Surgery is a terrifying experience for all ages. The fear psychosis of surgery in children is a traumatic experience because of unfamiliar and intimidating environment of the operation theatre and separation of the child from his/her parents.

Premedication is considered to be an essential part of anaesthetic technique. The objectives of premedication are to allay anxiety, assist induction of anaesthesia, provide analgesia, decrease autonomic (Vagal reflexes), reduce gastric secretion, $\&$ acidity and reduce salivation.(1)

The objective of the anaesthesiologist in planning the preoperative care and premedication of paediatric patients is

Financial or Other, Competing Interest: None.

Submission 16-06-2016, Peer Review 28-06-2016,

Acceptance 30-06-2016, Published 05-07-2016.

Corresponding Author:

Dr. Soumya Samal,

Assistant Professor

Department of Anaesthesiology,

IMS and SUM Hospital,

Bhubaneswar-751003, Odisha.

E-mail: samalsoumya11@gmail.com

DOI: $10.14260 /$ jemds/2016/832 to minimise the potential adverse physiological and psychological effects of anaesthesia and surgery. The goal is achieved only if the anaesthesiologist makes an individual assessment of each child, fully recognises the problem and then orders appropriate preoperative care.

The ideal premedication for children should be safe, easy to administer, and should be acceptable to children. It should ensure a rapid level of short-term sedation to facilitate a smooth separation from parents, smooth anaesthetic induction, and should have minimal undesirable side effects. Several significant changes in clinical practice have changed the focus of traditional premedication techniques, and there has been a definite shift towards oral, orotransmucosal, nasal, and rectal administration of drugs. Of these, the oral route is definitely most popular and acceptable.

Thus, keeping in mind, the efficacy, safety, and untoward effects of the premedicant drugs, the present study was conducted to compare the effects of midazolam and ketamine as oral premedication for paediatric anaesthesia.

\section{MATERIALS AND METHODS}

After obtaining ethical committee clearance and informed consent from parents, 100 patients of either sex (ASA I and II) in the age group of 3 to 8 years posted for elective surgery 
under general anaesthesia were included in this prospective randomised controlled study. The study was conducted in IMS and SUM Hospital Bhubaneswar from June to December 2015.

A detailed clinical assessment of each patient was done to exclude any underlying systemic disease. Detailed case history was taken in all cases. Pulse rate and blood pressure was checked and the weight of each patient was taken. Routine laboratory investigations such as haemogram, routine, and microscopic examination of stool and urine was done. Investigations like chest $\mathrm{x}$-ray, Mantoux test, blood sugar, serum urea and creatinine, liver function tests, serum electrolytes were advised if required. Any cases showing gross deviation from normal was excluded from the study.

Patients were also excluded from the study with history of intolerance to oral administration of drugs, drug allergy, convulsion and any kidney, liver, respiratory, cardiovascular, and neurological disorders.

For the purpose of this study, patients were randomly allocated into two groups of 50 each to receive either 0.75 $\mathrm{mg} / \mathrm{kg}$ midazolam (Group M) or $6 \mathrm{mg} / \mathrm{kg}$ ketamine (Group K) as oral premedication. Midazolam and ketamine were mixed with honey $(0.2 \mathrm{~mL} / \mathrm{kg})$ to make it palatable. Calculated dose of the drugs and honey were measured with the help of a plastic $2 \mathrm{~mL}$ syringe mixed by the anaesthetist and administered by the mother with the help of a teaspoon.

All the patients were visited in the evening before operation and a detailed clinical re-evaluation was done. Parents were explained about the preoperative preparation. Patients were not allowed to take milk or solid diet for 8 hours and clear fluid for 4 hours prior to surgery.

On the day of surgery, the patients were brought to the preanaesthesia room about 45 minutes before operation. In the pre-anaesthesia room, necessary arrangements were made for administration of the studied drugs, monitoring of the child, emergency drugs, and equipment to tackle any untoward effects of the drugs. Patients pulse rate, blood pressure, and body weight were recorded. In the pre-anaesthesia room, premedicants were given in presence of parents 30 minutes prior to proposed time of induction.

Thirty minutes following premedication patients were separated from their parents and brought to the operation theatre. Intravenous cannulation was done with appropriate size intravenous cannula. Patients were observed in relation to:

1. Age, sex, and weight.

2. Type of operation.

3. Level of sedation was assessed at $0,5,10,15,20,25,30$ minutes after premedication by using a 5 points sedation scale. (1-Barely arousable, 2-Asleep, 3-Sleepy, 4-Awake, 5-Agitated).

4. Time of onset of sedation: It is the time from oral premedication till the child is sleepy. (Score 3).

5. Anxiolysis (Emotional state): Emotional state of the children were observed during separation from their parents and at the time of venepuncture by using a 4point scale. (1-Calm and sleepy, 2-Apprehensive behaviour and withdrawn, 3-Crying, 4-Thrashing).

6. Effect of premedication on vital parameters.

7. Undesired effects in the pre and postoperative period: Increased secretion, vomiting, nystagmus, random limb movement, hallucination, and airway obstruction.
8. Anxiolysis at the time of venepuncture by using 4-point scale as described above.

9. Quality of induction was assessed by noting child's response to application of facemask and intravenous administration of drugs during induction by using 4-point scale. (1-Poor, afraid, combative, crying; 2-Fair, moderate fear at mask, easily calmed; 3-Good, slight fear at mask, easily calmed; 4-Excellent, unafraid, co-operative, accepts mask readily).

10. Postoperative questionnaire: 24 hours after surgical procedure, parents were asked whether their child was adequately relaxed at the time of separation to enter the operation theatre. Based on the parental response, it was 1) Pleasant, 2) Acceptable, and 3) Unpleasant.

Statistical analysis was done by using student's t test and chi-square test by using SPSS 22 version. Data were expressed as mean, standard deviation, and percentage. The $\mathrm{p}$ value of less than 0.05 was considered significant.

\section{RESULT}

\begin{tabular}{|c|c|c|c|c|c|}
\hline \multirow{2}{*}{ Group } & \multirow{2}{*}{$\begin{array}{c}\text { No. of } \\
\text { Patients }\end{array}$} & $\begin{array}{c}\text { Age in } \\
\text { Year } \\
\text { (mean } \pm \\
\text { SD) }\end{array}$ & Male & Female & $\begin{array}{c}\text { Body } \\
\text { Weight in } \\
\text { Kg (Mean } \pm \\
\text { SD) }\end{array}$ \\
\hline M & 50 & $5.6 \pm 1.4$ & $\begin{array}{c}30 \\
(60 \%)\end{array}$ & $\begin{array}{c}20 \\
(40 \%)\end{array}$ & $15.8 \pm 3.06$ \\
\hline $\mathrm{K}$ & 50 & $5.7 \pm 1.2$ & $\begin{array}{c}28 \\
(56 \%)\end{array}$ & $\begin{array}{c}22 \\
(44 \%)\end{array}$ & $16.02 \pm 3.07$ \\
\hline \multicolumn{5}{|c|}{ Table 1: Patient Demography } \\
\hline
\end{tabular}

\begin{tabular}{|c|c|c|}
\hline $\begin{array}{c}\text { Surgical } \\
\text { Procedure }\end{array}$ & $\begin{array}{c}\text { Group M } \\
(\mathbf{N = 5 0 )}\end{array}$ & $\begin{array}{c}\text { Group K } \\
(\mathbf{N = 5 0 )}\end{array}$ \\
\hline Tonsillectomy & 12 & 15 \\
\hline Mastoidectomy & 18 & 14 \\
\hline Circumcision & 06 & 04 \\
\hline $\begin{array}{c}\text { Cleft lip and cleft } \\
\text { palate }\end{array}$ & 12 & 14 \\
\hline $\begin{array}{c}\text { Repair of } \\
\text { Inguinal hernia }\end{array}$ & 02 & 03 \\
\hline \multicolumn{2}{|c|}{ Table 2: Type of Surgery } \\
\hline
\end{tabular}

\begin{tabular}{|c|c|c|c|c|c|c|c|}
\hline Scores & $\begin{array}{c}\text { Before } \\
\text { Premedication }\end{array}$ & $\begin{array}{c}\mathbf{5} \\
\text { min }\end{array}$ & $\begin{array}{c}\mathbf{1 0} \\
\text { min }\end{array}$ & $\begin{array}{c}\mathbf{1 5} \\
\text { min }\end{array}$ & $\begin{array}{c}\mathbf{2 0} \\
\text { min }\end{array}$ & $\begin{array}{c}\mathbf{2 5} \\
\text { min }\end{array}$ & $\begin{array}{c}\mathbf{3 0} \\
\text { min }\end{array}$ \\
\hline \multicolumn{7}{|c|}{ Group M } \\
\hline 5 & 12 & 0 & 0 & 0 & 0 & 0 & 0 \\
\hline 4 & 38 & 50 & 44 & 15 & 3 & 0 & 0 \\
\hline 3 & 0 & 0 & 6 & 35 & 34 & 17 & 10 \\
\hline 2 & 0 & 0 & 0 & 0 & 13 & 31 & 33 \\
\hline 1 & 0 & 0 & 0 & 0 & 0 & 2 & 7 \\
\hline Total & $\mathbf{5 0}$ & $\mathbf{5 0}$ & $\mathbf{5 0}$ & $\mathbf{5 0}$ & $\mathbf{5 0}$ & $\mathbf{5 0}$ & $\mathbf{5 0}$ \\
\hline \multicolumn{7}{|c|}{ Group K } \\
\hline 5 & 10 & 0 & 0 & 0 & 0 & 0 & 0 \\
\hline 4 & 40 & 50 & 0 & 33 & 11 & 0 & 0 \\
\hline 3 & 0 & 0 & 0 & 17 & 35 & 24 & 13 \\
\hline 2 & 0 & 0 & 0 & 0 & 4 & 26 & 32 \\
\hline 1 & 0 & 0 & 0 & 0 & 0 & 0 & 5 \\
\hline Total & $\mathbf{5 0}$ & $\mathbf{5 0}$ & $\mathbf{5 0}$ & $\mathbf{5 0}$ & $\mathbf{5 0}$ & $\mathbf{5 0}$ & $\mathbf{5 0}$ \\
\hline \multicolumn{7}{|c|}{ Table 3: Level of Sedation } \\
\hline
\end{tabular}

Both the groups were similar in demographic profile and type of operative procedures (Table 1 and 2). Table 3 shows 
sedation score at different time intervals in both the groups. Score 3 was considered as an acceptable level of sedation.

After 25 minutes of premedication before the time of separation of the children from their parents, all of them in both the groups were sleepy (Score 3 or less).

\begin{tabular}{|c|c|c|}
\hline Emotional Scale & Group M & Group K \\
\hline $\begin{array}{c}\text { Score 1 } \\
\text { (Calm and } \\
\text { sleepy) }\end{array}$ & $33(66 \%)$ & $28(56 \%)$ \\
\hline $\begin{array}{c}\text { Score 2 } \\
\text { (Apprehensive) }\end{array}$ & $10(20 \%)$ & $11(22 \%)$ \\
\hline Score 3 (Crying) & $05(10 \%)$ & $07(14 \%)$ \\
\hline $\begin{array}{c}\text { Score 4 } \\
\text { (Thrashing) }\end{array}$ & $02(04 \%)$ & $04(08 \%)$ \\
\hline \multicolumn{2}{|c|}{ Total } & $\mathbf{5 0}$ \\
\hline \multicolumn{2}{|c|}{ Table 4: Anxiolysis Score During } \\
\hline
\end{tabular}

\begin{tabular}{|c|c|c|c|c|}
\hline Timing & $\begin{array}{c}\text { Pulse } \\
\text { Rate Per } \\
\text { Minute }\end{array}$ & $\begin{array}{c}\text { Systolic } \\
\text { Blood } \\
\text { Pressure } \\
\text { (mm Hg) }\end{array}$ & $\begin{array}{c}\text { Diastolic } \\
\text { Blood } \\
\text { Pressure } \\
\text { (mm Hg) }\end{array}$ & $\begin{array}{c}\text { Respiratory } \\
\text { Rate Per } \\
\text { Minute }\end{array}$ \\
\hline \multicolumn{5}{|c|}{ Group M } \\
\hline $\begin{array}{c}\text { Before } \\
\text { premedication }\end{array}$ & $106 \pm 5.3$ & $98 \pm 9.6$ & $68 \pm 6.4$ & $21 \pm 2$ \\
\hline $\begin{array}{c}15 \text { min. after } \\
\text { premedication }\end{array}$ & $101 \pm 3.6$ & $96 \pm 8.8$ & $64 \pm 4.8$ & $22 \pm 4.3$ \\
\hline $\begin{array}{c}30 \text { min. after } \\
\text { premedication }\end{array}$ & $103 \pm 8.5$ & $101 \pm 5.4$ & $70 \pm 3.1$ & $20 \pm 2.7$ \\
\hline \multicolumn{5}{|c|}{ Group K } \\
\hline $\begin{array}{c}\text { Before } \\
\text { premedication }\end{array}$ & $101 \pm 7.6$ & $98 \pm 8.4$ & $70 \pm 5.3$ & $20 \pm 3.8$ \\
\hline $\begin{array}{c}15 \text { mins after } \\
\text { premedication }\end{array}$ & $108 \pm 6.4$ & $104 \pm 5.7$ & $74 \pm 7.4$ & $21 \pm 4.4$ \\
\hline $\begin{array}{c}30 \text { mins after } \\
\text { premedication }\end{array}$ & $105 \pm 4.8$ & $100 \pm 4.6$ & $72 \pm 6.3$ & $22 \pm 2.5$ \\
\hline \multicolumn{7}{|c|}{ Table 5: Effect of Premedication on Vital Parameters } \\
\hline
\end{tabular}

(Mean \pm SD)

Midazolam found to have better anxiolytic action than ketamine $(\mathrm{P}<0.05)$. Table 4 shows in midazolam group 33 (66\%) children were calm and sleepy during separation from their parents where as it was $28(56 \%)$ with ketamine. The mean time of onset of sedation in group $M$ patients was $16.2 \pm$ 3.6 minutes and in group $\mathrm{K}$ was $19.4 \pm 3.2$ minutes $(\mathrm{P}<0.001)$. There was no significant change in the vital parameters before induction of anaesthesia among both the groups (Table 5).

\begin{tabular}{|c|c|c|}
\hline Parameters & Group M & Group K \\
\hline Increased secretions & $3(6 \%)$ & $12(24 \%)$ \\
\hline Vomiting & $2(4 \%)$ & $7(14 \%)$ \\
\hline Nystagmus & $0(0 \%)$ & $28(56 \%)$ \\
\hline $\begin{array}{c}\text { Random limb } \\
\text { movement }\end{array}$ & $3(6 \%)$ & $8(16 \%)$ \\
\hline $\begin{array}{c}\text { Airway support } \\
\text { required }\end{array}$ & $2(4 \%)$ & $3(6 \%)$ \\
\hline Hallucinations & 0 & 0 \\
\hline
\end{tabular}

Table 6: Incidence of Side Effects seen in Preoperative Period
As seen in table 6, there were more side effects like increased secretions, vomiting, nystagmus, and random limb movement in ketamine groups in the preoperative period.

Around 26 (52\%) children in midazolam group were calm and sleepy during venepuncture compared to 23 (46\%) ketamine group $(\mathrm{P}<0.05)$.

\begin{tabular}{|c|c|c|}
\hline Emotional Scale & Group M & Group K \\
\hline $\begin{array}{c}\text { Score-1 } \\
\text { (Calm and } \\
\text { Sleepy) }\end{array}$ & $26(52 \%)$ & $23(46 \%)$ \\
\hline $\begin{array}{c}\text { Score-2 } \\
\text { (Apprehensive) }\end{array}$ & $11(22 \%)$ & $10(20 \%)$ \\
\hline Score-3 (Crying) & $10(20 \%)$ & $11(22 \%)$ \\
\hline $\begin{array}{c}\text { Score-4 } \\
\text { (Thrashing) }\end{array}$ & $03(6 \%)$ & $06(12 \%)$ \\
\hline \multicolumn{2}{|c|}{ Total } & $\mathbf{5 0}$ \\
\hline Table 7: Anxiolysis Score at the Time of Venepuncture \\
\hline
\end{tabular}

\begin{tabular}{|c|c|c|}
\hline Induction Score & Group M & Group K \\
\hline Poor-1 & $3(6 \%)$ & $5(10 \%)$ \\
\hline Fair- 2 & $4(8 \%)$ & $6(12 \%)$ \\
\hline Good-3 & $16(32 \%)$ & $17(34 \%)$ \\
\hline Excellent-4 & $27(54 \%)$ & $22(44 \%)$ \\
\hline T0TAL & $\mathbf{5 0}$ & $\mathbf{5 0}$ \\
\hline \multicolumn{3}{|c|}{ Table 8: Quality of Induction } \\
\hline
\end{tabular}

Midazolam had a superior degree of induction as shown in table 8. Induction score was excellent in 27 (54\%) children in midazolam group as compared to ketamine 22 (44\%). So, quality of induction is significantly better with midazolam than ketamine $(\mathrm{P}<0.05)$.

\begin{tabular}{|c|c|c|}
\hline Parameters & Group M & Group K \\
\hline Vomiting & $5(10 \%)$ & $8(16 \%)$ \\
\hline Nystagmus & $0(0 \%)$ & $6(12 \%)$ \\
\hline Crying & $27(54 \%)$ & $30(60 \%)$ \\
\hline Excitement & $4(8 \%)$ & $6(12 \%)$ \\
\hline $\begin{array}{c}\text { Airway } \\
\text { obstruction }\end{array}$ & $2(4 \%)$ & $4(8 \%)$ \\
\hline Hallucinations & $0(0 \%)$ & $0(0 \%)$ \\
\hline Table 9: Adverse Effects During Post-Anaesthetic Period \\
\hline
\end{tabular}

\begin{tabular}{|c|c|c|c|c|}
\hline Group & \multicolumn{4}{|c|}{ Parental Response } \\
\hline & Total & $\mathbf{1}$ & $\mathbf{2}$ & $\mathbf{3}$ \\
\hline \multirow{2}{*}{$\mathrm{M}$} & $\begin{array}{c}50 \\
(100 \%)\end{array}$ & $\begin{array}{c}39 \\
(78 \%)\end{array}$ & $\begin{array}{c}11 \\
(22 \%)\end{array}$ & $\begin{array}{c}0 \\
(0 \%)\end{array}$ \\
\hline \multirow{2}{*}{$\mathrm{K}$} & $\begin{array}{c}50 \\
(100 \%)\end{array}$ & $\begin{array}{c}30 \\
(60 \%)\end{array}$ & $\begin{array}{c}20 \\
(40 \%)\end{array}$ & $\begin{array}{c}0 \\
(0 \%)\end{array}$ \\
\hline \multicolumn{6}{|c|}{ Table 10: Results of Postoperative Questionnaires } \\
\hline
\end{tabular}

Adverse effects during post-anaesthetic period appear to be in favour of midazolam than ketamine. In the present study, airway support was required in $8 \%$ patients treated with ketamine compared to $4 \%$ in midazolam group (Table 9). Around $78 \%$ of the parents had pleasant experience with midazolam compared to $60 \%$ with that of ketamine (Table 10).

\section{DISCUSSION}

In our study, we found that oral midazolam $(0.75 \mathrm{mg} / \mathrm{kg})$ to be an effective anxiolytic than oral ketamine $(6 \mathrm{mg} / \mathrm{kg})$ with 
lower incidence of side effects. Midazolam, a water soluble benzodiazepine, is one of the most widely used oral premedication drugs in children.(1) Rapid onset and short duration of action with minimal side effects makes midazolam more favourable. (2) Oral premedication with midazolam 0.75 $\mathrm{mg} / \mathrm{kg}$ has shown better efficacy than $0.5 \mathrm{mg} / \mathrm{kg}$ or $1 \mathrm{mg} / \mathrm{kg}$ in terms of better sedation in paediatric patients. (3) Dillip Kothari et al compared the dose of oral midazolam between $0.5 \mathrm{mg} / \mathrm{kg}$ and $0.75 \mathrm{mg} / \mathrm{kg}$. They found oral midazolam in a dose of 0.75 $\mathrm{mg} / \mathrm{kg}$ offer effective sedation and better emotional control without fear of needle prick and side effects. ${ }^{(4)}$

The dose of oral ketamine in this study was selected as 6 $\mathrm{mg} / \mathrm{kg}$ body weight. Ketamine when used in higher dosage for oral premedication, side effects like increased salivation, secretion and subsequent airway obstruction, unconsciousness, postoperative vomiting, and increased muscle tone are more. Again, in lower dosage, it fails to provide uniform and satisfactory sedation, peaceful separation from parents, and smooth induction. S. Roy et al found that $6 \mathrm{mg} / \mathrm{kg}$ body weight dose of oral ketamine is virtually free from side effects in their dose response study.(5) One study observed effects of oral ketamine $3 \mathrm{mg} / \mathrm{kg}, 6 \mathrm{mg} / \mathrm{kg}$, and $8 \mathrm{mg} / \mathrm{kg}$ body weight and recommended the dose of $6 \mathrm{mg} / \mathrm{kg}$ as satisfactory and safe.(6)

Onset of sedation in group midazolam and group ketamine were $16.2 \pm 3.6$ and $19.4 \pm 3.2$ minutes respectively $(\mathrm{P}<0.001)$. Midazolam appeared as a better agent than ketamine considering onset of sedation. C. Suresh et al observed onset of sedation with oral midazolam $0.5 \mathrm{mg} / \mathrm{kg}$ as $15.4 \pm 3.5 \mathrm{~min}$ compared to $19.4 \pm 3.2$ minutes in patients receiving $5 \mathrm{mg} / \mathrm{kg}$ of oral ketamine.(7)

In our study, $66 \%$ of patients were calm and sleepy during separation from their parents with midazolam compared to $56 \%$ in ketamine group $(\mathrm{P}<0.01)$. Findings with midazolam was better in this study might be due to higher range of the dose used compared to other studies. $(7,8)$

In the present study, intravenous cannulation was possible in $80 \%$ patients of midazolam group and $72 \%$ patients of group ketamine. Gutstein et al (9) observed that intravenous cannulation was possible in $67 \%$ patients treated with oral ketamine as premedicant. Another study has shown children treated with midazolam were calm during venepuncture compared with ketamine.(10)

Cox et al concluded that oral midazolam is effective in reducing both separation and induction anxiety, which correlates with our study.(11) Induction score was excellent in $54 \%$ children with midazolam compared to $44 \%$ in ketamine group. Patel and Meakin also reported greater anxiolysis after oral midazolam than after a combination of diazepam and droperidol or trimeprazine.(12)

The incidence of secretion was observed to be $24 \%$ with oral ketamine as compared to $6 \%$ with oral midazolam. C Suresh et al has shown increased secretions in $20 \%$ cases with $6 \mathrm{mg} / \mathrm{kg}$ of oral ketamine.(7) Other side effects like vomiting, nystagmus, crying, excitement, and airway obstruction were found to be more with oral ketamine as shown by other studies. $(13,14,15)$

In the present study, $78 \%$ of the parents had pleasant experience with midazolam compared to $60 \%$ with that of ketamine. Midazolam produces anterograde amnesia by impairing the ability to acquire new information.(16) The amnestic effects of midazolam generally persist for 20 to 30 minutes.(17) Midazolam was found to provide partial or complete amnesia in $90 \%$ of children undergoing bone marrow aspiration.(18)

\section{CONCLUSION}

We conclude that midazolam $(0.75 \mathrm{mg} / \mathrm{kg})$ is effective than ketamine $(6 \mathrm{mg} / \mathrm{kg})$ as oral premedicant for children because of its early onset of action, better effect on allaying anxiety during separation from parents, and lesser side effects.

\section{REFERENCES}

1. Funk W, Jakob W, Reidl T, et al. Oral pre-anaesthetic medication for children: double blind randomised study of a combination of midazolam and ketamine vs midazolam or ketamine alone. $\mathrm{Br} \mathrm{J}$ Anaesth 2000;84(3):335-40.

2. Gutstein HB. Potential physiologic mechanism for ketamine-induced emergence delirium. Anaesthesiology 1996;84(2):474.

3. Mishra LD, Sinha GK, Rao BP, et al. Injectable midazolam as oral premedicant in paediatric neurosurgery. J Neurosurg Anaesthesiol 2005;17(4):193-8.

4. Kothari D, Chaurasia HK, Mehrotra A, et al. Oral midazolam for pre-anaesthetic medication in paediatric patients. Ind J Anaesth 2000;44:58-9.

5. Roy S, Rudra A, Ghosh BR. Oral ketamine as preanaesthetic medication in children. A dose related response study. J anaesth clin pharmaco 1994;10:277-9.

6. Mehrotra A, Chaurasia HK, Kothari D, et al. Oral ketamine for pre-anaesthetic medication in paediatric patients. Ind J Anaesth 2000;44:61-2.

7. Suresh C, Kulshrestha S, Jain A, et al. Oral premedication for paediatric ambulatory anaesthesia: a comparison of midazolam and ketamine. Ind J Anaesth 2000;44:41-6.

8. Alderson PJ, Lerman J. Oral premedication for paediatric ambulatory anaesthesia: a comparison of midazolam and ketamine. Can J Anaesth 1994;41(3):221-6.

9. Gutstein HB, Johnson KL, Heard MB, et al. Oral ketamine pre-anaesthetic medication in children. Anaesthesiology 1992;76(1):28-33.

10. Ghai B, Grandhe RP, Kumar A, et al. Comparative evaluation of midazolam and ketamine with midazolam alone as oral premedication. Paediatr Anaesth 2005;15(7):554-59.

11. Cox RG, Nemish U, Ewen A, et al. Evidence-based clinical update: does premedication with oral midazolam lead to improved behavioural outcomes in children. Canadian Journal of Anaesthesia 2006;53(12):1213-9.

12. Patel D, Meakin G. Oral midazolam compared with diazepam-droperidol and trimeprazine as premedicants in children. Paediatric Anaesthesia 1997;7(4):287-93.

13. Tobias JD, Philips S, Smith B, et al. Oral ketamine premedication to alleviate the distress of invasive procedures in paediatric oncology patients. Paediatrics 1992;90(4):537-41.

14. Donahue PJ, Dineen PS. Emergence delirium following oral ketamine. Anaesthesiology 1992;77(3):604-5.

15. Joshi G, Dave CR. Oral ketamine premedication in paediatric patients. Ind J Anaesth 1994;42:342-5.

16. Veselis RA, Reinsel RA, Alagesan R, et al. Cognitive mechanism of amnesia produced by midazolam. Anaesthesiology 1990;73:189. 
17. Magni VC, Frost RA, Leung JW, et al. A randomized comparison of midazolam and diazepam for sedation in upper gastrointestinal endoscopy. British journal of Anaesthesia 1983;55(11):1095-101.
18. Sievers TD, Yee JD, Foley ME, et al. Midazolam for conscious sedation during paediatric oncology procedures: safety and recovery parameters. Paediatrics 1991;88(6):1172-9. 